\title{
Banking competition and its development in Russia
}

\author{
Yury Korobov ${ }^{1, *}$ \\ ${ }^{1}$ Saratov Socio-Economic Institute (branch of Plekhanov Russian Economic University), Department \\ of Banking, Money \& Credit, 410003 Saratov, Russia
}

\begin{abstract}
The article discusses theoretical issues of banking competition as well as its ifluences on the development of banking system (transformation of the essence of a bank; change of the target setting in banking; transfer of emphasis from operations to services; universalization of banking; transition from individual services to integrated banking products; change of priority from price to non-price methods of competition; transition from extensive to intensive type of network development; increasing the role of near-banks and nonbank banks). Factors influencing banking competition in Russia are shown: both restraining (reduction in the number of banks; concentration of assets at the largest banks; uneven territorial distribution of banks; local character of banking markets) and strengthening (financial globalization; digitalization of economy; forming of new banking culture).
\end{abstract}

Key words: banking system, banking market, banking competition, banking product, methods of competition, factors of competition, financial globalization, digitalization of economy, banking culture

\section{Introduction}

Competition is one of the most important characteristics of banking markets. Strengthening of banking competition in the leading countries occurred throughout the 20th century. Therefore, it is not surprising that interest in the problems of banking competition in our country (in particular, the author of these lines) arose simultaneously with the emergence of the first sprouts of the market economy in the early 1990s.

Nowadays we can see that banking sector undergoes profound transformations [1], and one of the main driving forces of these transformations is the development of competition. Therefore, it seems to be interesting to consider the essence of banking competition, as well as to give an overview of its development in Russia.

General problems of competition have been studied by many authors, beginning with the classics of economic science and theory of management, such as Marx [2], Hilferding [3], Chamberlin [4], Robinson [5], Hayek [6], Porter [7], and ending with contemporary authors such as Yudanov [8], Rubin [9],etc.

Theoretical issues of banking competition were discussed in works of such scientists as Aust [10], Griesel [11], Miretsky [12], Samoylov and Bachalov [13], Petrov [14], etc. Since

\footnotetext{
*Corresponding author: yurikor1965@gmail.com
} 
1994 banking competition became the main subject of research by the author of these article $[15,16]$.

Applied aspects of banking competition are covered in many publications, among which are articles of Tabacco [17], Cornaggia, Mao, Tian \& Wolfe [18], Fernández, González \& Suárez [19], Jayakumar, Pradhan, Dash, Maradana \& Gaurav [20], etc.

However, despite the fact that the issues of banking competition are of great theoretical and no less practical interest, their coverage in the economic literature remains rather modest. This determines the relevance of the topic of this article.

The purpose of the article is to discuss the specific features of banking competition and its influence on the development of banking system, as well as show factors influencing banking competition in Russia.

\section{Theoretical background: specific features of banking competition}

Banking competition is much more difficult than competition in any other sector of economy. Specific features of banking competition are determined by: 1) composition of participants; 2) structure of the sphere of competition; 3) specific features of the product; 4) forms of competition; 5) influence on other spheres of the economy and public life.

Participants of banking competition. The main participants of banking competition are commercial banks. However, banks are not the only competitors in the banking market. There are two other groups of competitors: near-banks and nonbank banks. The first group include financial institutions that are not formally banks, but offer a product similar to banking products (pawnshops, leasing companies, factoring companies, forfeiting companies, pension funds, insurance companies, investment companies, clearing houses, plastic card systems, trust companies, etc.). The second group includes non-financial enterprises whose main activities are not related to the financial sphere, but, nevertheless, are introduced into the banking market (mail, industrial enterprises, trade and service organizations, etc.). Introducing a particular banking product to the market, a commercial bank almost always faces competition not only from other commercial banks, but also from listed organizations. Thus, banking competition cannot be defined as a rivalry between banks, it is more correct to define it as a rivalry between all participants of the banking market. No other sphere of the economy has such a heterogeneous composition of participants.

Sphere of banking competition. The peculiarity of the banking market, which is the sphere of banking competition, is the complexity and diversity of its internal structure. The banking market consists in fact of a number of different markets, the main of which are the market of credit services, the market of deposit and investment services, the market of cash and settlement services, the market of currency services, the market of trust services and the market of consulting services. Each of the listed banking markets, in turn, consists of a number of banking industries, which should be understood as markets for individual banking services.

Unfortunately, the term "banking industry" in literature and in practice is often used to refer to the whole sphere of banking activity, as a synonym for "banking sector" or "banking". But if we assume that the industry is a group of enterprises that produce similar or interchangeable goods or services, the banking market on which a multitude of diverse products and services are sold cannot be recognized as a single industry. For example, there is nothing in common in attracting deposits from the population and issuing loans to multinational companies. It is difficult to find more dissimilar activities. According to Porter's remark, it is the same as comparing the production of steel with the production of motion pictures [21]. Thus, banking is not a single industry, but rather a set of industries 
and branches, and each of them deserves carrying a specific analysis and developing a separate competitive strategy.

Banking product. A banking product should be understood as a separate banking service or a package (package) of interrelated services. The peculiarities of banking product are intangibility, complexity for perception, inseparability from the source, impermanence of quality, non-conservation, contractual nature, connection with money, length of service in time, secondary nature of satisfied needs.

From the bank's point of view, all these features are negative, since they lead to the formation of barriers (basically, psychological) between the bank and its clients. As a result, banking products a priori lose in attractiveness in comparison to material goods, and it brings difficulties for banks in promotion their products to their customers.

Forms of competition. In addition, due to the high level of risks in the banking sector there is not only individual, but also group competition. Various types of banking associations are formed, within which competition is completely or partially replaced by cooperation. Unions can be created both on a non-commercial and on a commercial basis (for example, for consortial lending).

Socio-economic impact. Any competition is a sort of natural selection, during which the strongest wins. Those who are not competitive, suffer losses or even become bankrupt. But while in many spheres of the economy (industry, commerce, agriculture, etc.), the bankruptcy of a competitor will be reflected mainly on its employees and creditors, the "circles on the water" caused by bankruptcy of a bank are much broader and more destructive. Bankruptcy of one bank can provoke anxiety of depositors of other banks and mass withdrawal of their deposits. This, in turn, may cause problems with liquidity in the banking community, which will affect counterparties and depositors of all banks, and lead to a system crisis. Thus, banking competition, being a microeconomic phenomenon, is capable of providing macroeconomic impact.

Since the results of banking competition are not indifferent to society due to their significant socio-economic impact, it cannot remain outside the sphere of state regulation. As a rule, in all countries large system-forming banks have "immunity" from bankruptcy and can rely on the state in critical situations. Also the state should make efforts to control the unfair competition, because it can undermine the clients' confidence in the banking system.

\section{Influence of competition on the development of the Russian banking system}

Currently, in Russia, as in many other countries, the banking system is changing, and the main driving force behind the changes is the strengthening of banking competition.

Specific manifestations of the influence of competition on banking system are: 1) transformation of the essence of a commercial bank; 2) change of the target setting in banking activities; 3 ) transfer of emphasis in banking activities from operations to services; 4) universalization of banking activities; 5) transition from provision of individual services to integrated banking products; 6) change of priority from price to non-price methods of banking competition; 7) transition from extensive to intensive type of banking branch network development; 8) increasing the role of near-banks and nonbank banks.

Transformation of the essence of a commercial bank. The concept of a bank as an institution changed to the concept of a bank as an enterprise. There is a formation of a new banking culture in all aspects - intra-corporate culture, social culture, culture of relations with customers, partners, competitors.

Change of the target setting in banking activities. For a long period of time, the main purpose of a commercial bank was to gain profit. However, already in the last third of the 
20th century, as a result of the introduction of marketing, the satisfaction of customers' needs is shifted to the top of the pyramid of objectives of a commercial bank, pushing the profit gain to the background. This trend can further be seen in the development of social and ethical marketing concepts, as well as in spreading of Islamic banking model.

Transferring the focus in banking activities from operations to services. In current conditions of intensive banking competition, it is necessary for bank employees to consider their activities not only as technical implementation of operations, but primarily as providing services to consumers. This, in turn, changes the requirements for the qualification of a bank employee, increasing the importance of communication skills.

Universalization of banking activities. The diversification of banking activity that took place in the 20th century led to the prevailing of universal banks in most countries.

Transition from the provision of individual services to integrated banking products. This allows to simultaneously take into account the interests of customers, whose needs are often complex, and the interests of the bank, aimed at expanding their sales volume.

Change of priority from price to non-price methods of banking competition. Basically, any bank offers pretty much the same assortment of services as all other banks, therefore banking competition a priori should be price-based. However, due to the economic, legal and psychological limitations of price methods, banks are making significant efforts to differentiate their products, to ensure consumers' loyalty based on the image formation. Today, to ensure their competitiveness, banks use a complex set of price and non-price methods of competition (with a gradual shift of priorities in the direction of non-price competition).

Transition from extensive to intensive type of banking branch network development. While in the 20th century in many countries (including Russia) there was a significant increase in the number of commercial banks and an intensive expansion of their branch network, the main trends of the 21 st century are increase in bank capital concentration and rationalization of banking branch network.

Increasing the role of near-banks and nonbank banks. Some of these organizations are comparable to banks in terms of financial strength (investment companies, insurance companies, etc.), and their number is growing.

\section{Factors influencing banking competition in Russia}

Many factors influence the development of banking competition in Russia. At the same time, some of them have a deterrent effect on bank competition, while others have a stimulating effect.

Factors which are restraining banking competition in Russia are: 1) important role of the state in functioning of banking system; 2) reduction in the number of banks; 3) concentration of assets at the largest banks; 4) uneven territorial distribution of banks; 5) local character of regional banking markets.

Important role of the state in the formation of banking system. In most Western countries, the "pioneers" of the banking market were non-state banks, the state began to actively influence the banking sector only in 19th century, with the emergence of central banks. Moreover, even some central banks have existed for a long time on the basis of private property (for example, the Bank of England was nationalized only in 1946).

In Russia, banking was originally developed as a sphere of activity of the state. The first banks, which appeared in the 1730 s, were state-owned. The functions of the central bank were entrusted to the State Bank of the Russian Empire, established in 1860. Private commercial banks began to develop only from the $1860 \mathrm{~s}$. The nationalization of banks in the Soviet period led to the state monopoly of banking. 
The revival of private banks occurred during the commercialization of the banking system in the 90 s of the 20 th century.

Reduction in the number of banks. In the first 5-6 years of operation of the market banking system in Russia, there was an exceptionally intensive growth in the number of commercial banks and other participants in the banking market. By 1995, there were more than 2,500 commercial banks. However, in the second half of the 1990s, the number of Russian banks began to decrease, which was due to the financial crisis and subsequent state policy aimed at restructuring of the banking system. As of 01.08.2018, only 476 functioning banks are remaining [22]. As a result, there is a significant gap in terms of the number of banks and their branches per capita between Russia and countries with developed economies.

Concentration of assets at the largest banks. In fact, the main players of the Russian market are only about 20 the largest banks. The share of the 20 largest banks as of 01.08 .2018 accounted for $79.9 \%$ of all banking assets, including $59.8 \%$ - to the 5 largest banks [22].

Uneven territorial distribution of banks. Today, about $50 \%$ of all Russian banks are territorially located in the Moscow region. These banks control over $90 \%$ of banking assets [22].

Local character of regional banking markets. Historically most of the banks in regions of Russia used to have a local orientation and their branch network did not go beyond the borders of the home region. Therefore competition on every single regional banking market was almost only between local banks, and the country's banking market was split into many relatively isolated local markets. However, the development of information technologies and the widespread introduction of remote banking services are gradually erasing the boundaries between regional banking markets.

On the other side, there are factors which are strengthening banking competition in Russia: 1) financial globalization; 2) digitalization of economy; 3) forming of new banking culture. Consider these factors in more detail.

\section{Impact of financial globalization}

Intensity of banking competition in developed countries pushes their banks to go beyond national borders. My previous studies led to the conclusion that the process of globalization forces to reconsider the established idea of the essence of the banking system [1]. Today we should abandon the interpretation of banking system as the set of credit institutions within a specific country. The banking system of the 21 st century is essentially an international one.

The most visible process of transformation of the national banking system into an international one has manifested itself in the countries of Western Europe, but some of its manifestations are also present in Russia. In 2000s, there has been a steady trend towards increased penetration of foreign banking capital into Russian banking market. Now 115 out of 476 Russian banks (24.2\%) have a non-resident share in their authorized capital [22].

The influence of financial globalization on the banking system of Russia is ambiguous. On the one hand, the inflow of foreign bank capital contributes to the expansion of assortment and quality of banking services, introduction of international banking standards, creation of new jobs, increase of tax revenues to the state budget, and attraction of foreign investments. On the other hand, banking globalization can lead to an increase in the dependence of the country's economy on foreign capital. This brings up the need to increase the competitiveness of national banking system.

In my opinion, there are two main approaches to assessing the competitiveness of the national banking system: 1) assessment of the competitiveness of individual banks; 2) assessment of the competitiveness of banking system as a whole. 
The competitiveness of individual banks is determined by their competitive advantages and affects the financial results of their activities.

Main factors of competitiveness of individual banks are:

- resources (capital, borrowed funds);

- the level of costs (makes impact on interest rates and fees);

- product differentiation (quality and assortment of services, bank's image).

The competitiveness of banking system as a whole can be defined as its resistance to external influences. It affects the stability of the monetary system of the country and the economy as a whole.

Main factors of competitiveness of banking system as a whole are:

- economic factors (availability of credit resources and qualified personnel; developed infrastructure; quantitative and qualitative level of demand for banking services; intensity of banking competition; competitiveness of the economy as a whole);

- political and legal factors (conditions of licensing of banks, supervision standards, legislative protectionism);

- socio-cultural factors (national psychology, level of knowledge, banking culture);

- technological factors (modern information technologies).

The advantages of the Russian banking system include a large resource potential, adequate regulation, and susceptibility to technology. But at the same time, there are a number of "bottlenecks": underdeveloped infrastructure, indiscriminate demand, sluggish competition.

Thus, in Russia there is a need to establish a system of measures to strengthen the competitiveness of the national banking system. These measures should include:

- improvement of the competitiveness of individual banks (capital increase, optimization of internal structure, improvement of the range of banking services and the level of customer service);

- development of banking infrastructure (adaptation of the regulatory framework to modern conditions, modernization of information and methodological subsystems banking infrastructure, increase of banking market transparency);

- raise of awareness and economic literacy of bank customers, primarily in retail banking;

- formation of marketing thinking among bank employees, development of communication abilities, etc.

\section{Impact of digitalization}

In the context of digitalization of the economy, the introduction of information technologies is becoming one of the most important factors affecting the development of all sectors of the economy. The influence of this factor on competition in banking sector is primarily manifested in impact on the characteristics of banking services.

As mentioned above, specific features of banking services are their intangibility, complexity for perception, inseparability from the source, impermanence of quality, nonconservation, contractual nature, connection with money, length of service in time, secondary nature of satisfied needs. From the point of view of a bank, these features play generally negative role, since most of them lead to the formation of barriers between a bank and their customers (mainly psychological). As a result, banking services a priori lose in attractiveness to material goods, and it is more difficult for banks to carry out promotion of their products than for enterprises in the sphere of material production. Let's see what is changing with the introduction of information technologies in banking, examining each specifuc feature of banking services. 
Intangibility of banking services. Services have no material substance, they can not be perceived by the senses. In this regard, consumers show increased attention to external elements of service - equipment, forms of documents, etc. (figuratively speaking, "the wrapper of banking services"). Of course, with introduction of information technologies banking services do not become tangible. However, the transfer of market relations to the information environment, where all goods are virtual, deprives sellers of material goods of their advantages over sellers of services.

Complexity for perception. Unlike many other types of services, use of banking servicing requires a certain cultural and educational level of consumers. To facilitate the perception of banking services by the customers banks are providing them with personal advice and information materials explaining the the benefits of banking services. The development of information technologies, does not simplify the content of services, but significantly expands the possibilities of bank's explanatory activities. For example, reference materials placed on banking websites take full advantage of multimedia technologies, and the use of hypertext adds an element of interactivity.

Inseparability from the source. The service does not exist separately from its provider. Buyers of material products (for example, food) first of all they pay attention not on the source (in most cases they have no chance to visit the producer), but on the product itself. In contrast, bank customers normally could not use the service without visiting the bank, and could not be indifferent to personal qualities of bank employee (appearance, knowledge, communication skills, etc.) or to exterior and interior view of bank office (location, design, etc.). When a customer uses services through internet or mobile banking interface, the physical localization of the source ceases to play a big role, and the cost of creating a website is not comparable to the cost of construction of buildings and their design.

Impermanence of quality. Although many banking institutions offer clients a similar or even the same range of services, the absolute identity of banking products (such as in mass production in industry) is not achievable. Many banking services involve intensive communication between clients and employees, and employees may hsve different levels of technical and communication skills, different attitudes to work, etc. Moreover, the same employee may show different levels of service depending on the situation, mood, health, etc. Digitalization gives banks a chance to eliminate impermanence of quality in providing standardized services. The era of "mass production" of banking services began with the emergence of ATMs that provide services to all customers equally, regardless of the time of day, queue length, behavior or appearance of the customer. The same is true for internet banking, mobile banking, etc.

Non-conservation of banking services. Services can not be stored and conserved, they can not be "prepared for the future". At the same time, the volume of customer demand is constantly changing, it can be different on different days of the week and even at different times of the day. As in the previous case, a partial solution to this problem has been already found with the development of ATMs, and contemporary digitalization offers more advanced solutions.

Contractual nature of banking services. The provision of the absolute majority of banking services involves the conclusion of civil contracts between the bank and the customer. This creates certain difficulties for customers, and banks are facing the need for a thorough explanation of the content of banking services and the contractual terms of their provision to the customers, and ultimately - for gaining the trust of the customers. Thus, the customer service in a bank become partly similar to educational activity. This "distrust factor" does not disappear even in the new digital era. On the contrary, one of the main problems today is the lack of adequate legal regulation of many aspects of digital economy (cryptocurrency, etc.). 
Connection of banking services with money. People pay special attention to everything related to money, and this also makes the bank's activities dependent on the clients' trust and requires efforts aimed at strengthening this trust. Although the essence of services does not change with the change of technology, the fact that in the information space money functions only in cashless form, to some extent reduces the internal psychological barrier of the customers (non-cash money is easier to spend).

Length of banking service in time. When providing most banking services, the client enters into a more or less long-term relationship with the bank. This, like two previous features, attaches particular importance to the trust-based nature of the bank-client relationship. In fact, for example, when opening an account, the client trusts the bank with his/her money and enters into a transaction, the course of which is initially uncontrollable for him/her. New information technologies provide the customer with the opportunity to receive more detailed information at the stage of choosing a bank for servicing.

Secondary nature of satisfied needs. Banking services don't satisfy the primary needs of customers (i.e. food, clothing, housing, etc). They are designed to satisfy financial needs (which are derived from primary needs). As a result, banking services lose in attractiveness to material products as well as to services which directly meet primary needs of consumers (i.e. health care, etc.). This complicates the task to promote banking services on the market and requires additional efforts from banks. Although information technology does not change the nature of needs, it provides banks with additional opportunities to satisfy these needs. In addition, transactions with material product carried out in digital space do not provide immediate satisfaction of needs, it always takes time to deliver product to the consumer.

Our analysis showed that the development of information technologies can significantly "shorten the distance" between producers and consumers of banking services. Russian banks almost do not lag behind Western banks in terms of digital innovation, so the development of information technologies is nowadays one of the main factors in strengthening banking competition in Russia.

\section{Impact of new banking culture}

As has been shown in my previous research, banking culture in the broadest sense can be defined as a set of principles of behavior of all subjects of banking activity - banks, banking customers and social institutions that ensure the functioning of the banking system. According to this, there are three levels of banking culture: corporate banking culture, consumer banking culture and social banking culture [1].

The elements of the corporate banking culture are the internal banking rules (appearance, rules of conduct in the workplace, correspondence, telephone conversations), a set of professional competencies of bank employees, the culture of communication with customers, corporate identity (branding), management culture (leadership style), banking strategy, culture of competition, principles of relations with the state and society.

Elements of the consumer banking culture are the financial literacy of bank customers and their willingness to use banking services.

Elements of the social banking culture are banking legislation, the development strategy of the banking system, regulation of bank competition (antitrust measures, combating unfair competition), banking supervision, banking culture of the mass-media. The high risks inherent to the banking system call for the regulation of its activity by the state, and a calm and balanced attitude from mass-media.

In modern Russia, changes are taking place at all three levels of banking culture. The corporate banking culture is changing under the influence of banking competition, Russian banks are becoming more customer-oriented and more receptive to innovation - both in 
terms of the development of new banking products and in terms of the introduction of new financial technologies, as well as techniques of promotion and sale.

The main change in the consumer banking culture in Russia is connected with the growth of financial literacy of bank customers. Bank customers become more and more demanding in choosing a bank for servicing, providing more incentives for banks to increase their level of competitiveness.

Changes in the social banking culture are manifested primarily in improving the regulation of the banking sector. One of the manifestations of this is the presence of the state strategy for the development of banking sector. In Russia strategies of development of the banking sector were developed in 2005, 2008 and 2011. Since Bank of Russia received in 2013 the status of a mega-regulator of all financial markets of Russia, new strategy is called Main directions of development of financial market of Russian Federation.

In general, the formation of a new banking culture has an important impact on the development of banking competition and the competitiveness of the Russian banking system.

\section{Conclusion}

Banking competition is the main driving force behind the changes occurring in contemporary banking system. Specific manifestations of the influence of competition on banking system are: transformation of the essence of a bank; change of the target setting in banking; transfer of emphasis from operations to services; universalization of banking; transition from individual services to integrated banking products; change of priority from price to non-price methods of competition; transition from extensive to intensive type of network development; increasing the role of near-banks and nonbank banks.

In turn, the development of banking competition in Russia is influenced by many factors, some of which have a deterrent effect on bank competition, while others have a stimulating effect. Factors restraining banking competition in Russia are: reduction in the number of banks; concentration of assets at the largest banks; uneven territorial distribution of banks; local character of banking markets. Factors strengthening banking competition in Russia are: financial globalization; digitalization of economy; forming of new banking culture.

The impact of financial globalization brings up the need to establish in Russia a system of measures to strengthen the competitiveness of the national banking system which should include: improvement of the competitiveness of individual banks; development of banking infrastructure; raise of awareness and economic literacy of bank customers, primarily in retail banking; formation of marketing thinking among bank employees.

The influence of digitalization on banking competition is primarily manifested in impact on the characteristics of banking services. Development of information technologies reduces barriers between producers and consumers of banking services and leads to increased banking competition in Russia.

New banking culture consists of three levels - corporate banking culture, consumer banking culture and social banking culture. Changes at all this levels make an impact on the development of banking competition and the competitiveness of the Russian banking system.

\section{References}

1. Y. Korobov, Global banking: transformation, innovation \& competition. SHS Web of Conference - Innovative Economic Symposium 2017, 39(01012), (2017) 
2. K. Marx, Das Kapital. Kritik der politischen Ökonomie, Band 3: Der Gesamtprozess der kapitalistischen Produktion, (1894)

3. R. Hilferding, Das Finanzkapital. Eine Studie zur jüngsten Entwicklung des Kapitalismus, (1910)

4. E. Chamberlin, The theory of monopolistic competition: A re-orientation of the theory of value, (1933)

5. J. V. Robinson, The economics of imperfect competition, (1933)

6. F. Hayek, Der Wettbewerb als Entdeckungsverfahren. Kieler Vorträge, 56, (1968)

7. M. E. Porter, Competitive Strategy, (1980)

8. A. Y. Yudanov, Competition: Theory and Practice, (1998)

9. Y. B. Rubin, Competition: orderly interaction in professional business, (2006)

10. E. Aust, Der Wettbewerb in der Bankwirtschaft, (1963)

11. H. Griesel, Funktionsweise und charakteristische Merkmale des Bankenwettbewerbs als Gegenstand wissenschaftlicher Bankbetriebslehre. Bankbetriebliches Lesebuch, (1978)

12. A. P. Miretsky, Competitive position of the bank, (1999)

13. G. O. Samoylov, A. G. Bachalov, Banking competition, (2002)

14. M. A. Petrov, Banking competition and its features in Russia, (2004)

15. Y. I. Korobov, The theory of banking competition, (1996)

16. Y. I. Korobov, Practice of banking competition, (1996)

17. G. A. Tabacco, A new way to assess banking competition. Economics Letters, 121, (2013)

18. J. Cornaggia, Y. Mao, X. Tian, B. Wolfe, Does banking competition affect innovation? Journal of Financial Economics, 115, (2015)

19. A. I. Fernández, F. González, N. Suárez, Banking stability, competition, and economic volatility. Journal of Financial Stability, 22 (2016)

20. M. Jayakumar, R. P. Pradhan, S. Dash, R. P. Maradana, K. Gaurav, Banking competition, banking stability, and economic growth: Are feedback effects at work? Journal of Economics and Business, 96, (2018)

21. B. I. Deutsch, A conversation with Michael Porter. Bank Marketing, (1990)

22. Statistical bulletin of the Bank of Russia, 8 [online], Available at: https://www.cbr.ru/publ/BBS/Bbs1808r.pdf (2018) 